\title{
ПРОБЛЕМЫ НАЗНАЧЕНИЯ И ПРОИЗВОДСТВА СУДЕБНЫХ ЭКСПЕРТИЗ ПРИ ПРОВЕРКЕ СООБЩЕНИЙ О ПРЕСТУПЛЕНИЯХ В ЭКОНОМИЧЕСКОЙ ДЕЯТЕЛЬНОСТИ
}

\author{
Расулова Н.С.
}

\begin{abstract}
Аннотация: В данной статье приведен анализ современного состояния назначения и производства судебных экспертиз при проверке сообщений о преступлениях в экономической деятельности. Масштабы экономической преступности, ее распространенность, усилившаяся криминальная экспансия в экономику относятся к числу наиболее острых проблем в жизни общества и государства. Угрожая стабильности экономическим институтам, экономическая преступность превратилась в один из главных источников деструктивного воздействия на процессы социального, экономического и политического развития страны. На основании проведенного исследования выявлены противоречия и несовершенство уголовно-процессуального законодательства, препятствующие реализации назначения уголовного судопроизводства. Метод или методология исследования: Для достижения цели и решения задач, стоящих перед исследованием были применены общенаучные и частно-научные методы: анализ, синтез, структурно-логический метод, статистический и иные методы научного познания. Научная новизна и выводы: На основании проведенного анализа современного состояния назначения и производства судебных экспертиз при проверке сообщения о преступлениях в экономической деятельности, посредством использованных методов в статье сформулированы причины, являющиеся препятствием эффективного применения норм уголовно-проиессуального законодательства Российской Федерации. Ключевые слова: Проблема, производство, судебная экспертиза, сообщение, преступление, экономическая деятельность, Криминалистическая классификация, заключение эксперта, пробел, доказательство.
\end{abstract}

Указом Президента России от 12.05.2009 № 537 (в ред. от 01.07.2014) «О стратегии национальной безопасности Российской Федерации до 2020 года» одним из основных источников угроз национальной безопасности в сфере государственной и общественной безопасности определен сохраняющийся рост преступных посягательств, направленных против экономической безопасности, а также связанных с коррупцией [1].

Таким образом, целью расследования преступлений, совершаемых в экономической деятельности, является обеспечение экономической безопасности государства и хозяйствующих субъектов, служащей залогом достижения эффективного экономического роста в Российской федерации[2] . В связи с чем, правоохранительные органы нуждаются в эффективных научных рекомендациях и методических приемах, направленных на повышение качества работы по раскрытию и расследованию преступлений указанной категории, что в конечном итоге будет способствовать решению задач «охраны прав и свобод человека и гражданина, собственности, общественного порядка и общественной безопас- 
ности, окружающей среды, конституционного строя РФ от преступных посягательств, а также предупреждения преступлений» [3] .

Однако, анализ современного уголовно-процессуального законодательства и следственной практики показывает, что действующие нормы, касающиеся проверки сообщений о преступлениях в сфере экономической деятельности, не совершенны и требуют осмысления.

В уголовном праве под экономическими преступлениями понимаются запрещенные уголовным законом, умышленные общественно опасные деяния (действия и бездействия), посягающие на общественные отношения, обеспечивающие нормальное функционирование экономики, причиняющие или создающие возможность причинения вреда участникам экономических отношений, социальным ценностям и благам.

Криминалистическая классификация объединяет экономические преступления в группу посягательств, подпадающих при уголовно-правовой квалификации под признаки самых различных статей Уголовного кодекса Российской Федерации (кража, мошенничество, незаконное предпринимательство, незаконное получение кредита и т.д.).

В соответствии с Указаниями Генеральной прокуратуры и МВД Российской Федерации к «экономическим преступлениям» относятся некоторые преступления, совершенные против собственности:

- преступление, совершенное в процессе осуществления производственно-хозяйственной и финансовой деятельности либо под видом ее осуществления, в том числе в отношении юридических и физических лиц, осуществляющих предпринимательскую деятельность, независимо от формы собственности и организационно-правовой формы, официально зарегистрированных в качестве предпринимателей, а также объединений (граждан, юридических лиц), не являющихся юридическими лицами;

- преступления, предусмотренные ст. 159, $159.1,159.2,159.3,159.4,159.5,159.6$ УК РФ, совершенные физическими лицами с целью завладения имуществом граждан для осуществления производственно-хозяйственной и финансовой деятельности, а также под видом ее осуществления (например, финансовые пирамиды) [4].

Анализ официальных статистических данных ИЦ ГУ МВД России по Свердловской области за период 9 месяцев 2013-2014 г.г. позволяет сделать вывод, что наиболее распространенными преступлениями в экономической деятельности данного региона являются: мошенничество, присвоение и растрата, незаконное предпринимательство.

Так, за указанный период были выявлены следующие преступления:

- ст. 159 УК РФ «Мошенничество»: в 2013 г. возбуждено уголовных дел - 3021, в суд направлено - 1403, в 2014 г. возбуждено уголовных дел - 2813, в суд направлено - 1011;

- ст. 159.1 УК РФ «Мошенничество в сфере кредитования»: в 2013 г. возбуждено уголовных дел - 196, в суд направлено - 104, в 2014 г. возбуждено уголовных дел - 152, в суд направлено - 62;

- ст. 159.2 УК РФ «Мошенничество при получении выплат»: в 2013 г. возбуждено уголовных дел - 121, в суд направлено - 93, в 2014 г. возбуждено уголовных дел - 97, в суд направлено - 71;

- ст. 159.3 УК РФ «Мошенничество с использованием платежных карт»: в 2013 г. возбуждено уголовных дел -87 , в суд направлено - 54, в 2014 г. возбуждено уголовных дел - 53, в суд направлено - 39;

- ст. 159.4 УК РФ «Мошенничество в сфере предпринимательской деятельности»: в 2013 г. возбуждено уголовных дел - 61, в суд направлено - 11, в 2014 г. возбуждено уголовных дел - 82, в суд направлено - 26;

- ст. 159.5 УК РФ «Мошенничество в сфере страхования»: в 2013 г. возбуждено уголовных дел - 2, в суд направлено - 0, в 2014 г. уголовных дел не возбуждалось;

- ст. 159.6 УК РФ «Мошенничество в сфере компьютерной информации»: в 2013 г. возбуждено уголовных дел - 14, в суд направлено - 12, в 2014 г. возбуждено уголовных дел - 29, в суд направлено - 14.

- ст. 160 УК РФ «Присвоение или растрата»: в 2013 г. возбуждено уголовных дел - 897, в суд направлено - 690, в 2014 г. возбуждено уголовных дел - 706, в суд направлено - 669;

- ст. 171 УК РФ «Незаконное предпринимательство»: в 2013 г. возбуждено уголовных дел - 12, в суд направлено - 0, в 2014 г. возбуждено уголовных дел - 6, в суд направлено - 9 (из них 5, возбужденные в 2013 г.);

- ст. 165 УК РФ «Причинение имущественного ущерба путем обмана или злоупотребления доверием»: в 2013 г. возбуждено уголовных дел - 22, в суд направлено - 1, в 2014 г. возбуждено уголовных дел - 20, в суд направлено - 7;

- ст. 176 УК РФ «Незаконное получение кредита»: в 2013 г. возбуждено уголовных дел - 5, в суд направлено - 0, в 2014 г. возбуждено уголовных дел -3 , в суд направлено - 3; 
- ст. 170.1 УК РФ «Фальсификация единого государственного реестра юридических лиц, реестра владельцев ценных бумаг или системы депозитарного учета»: в 2013 г. возбуждено уголовных дел - 3, в суд направлено - 1, в 2014 г. возбуждено уголовных дел - 4, в суд направлено - 2;

- ст. 171.2 УК РФ «Незаконные организация и проведение азартных игр»: в 2013 г. возбуждено уголовных дел - 2, в суд направлено - 0, в 2014 г. возбуждено уголовных дел - 1, в суд направлено - 0 ;

- ст. 173.1 УК РФ «Незаконное образование (создание, реорганизация) юридического лица»: в 2013 г. возбуждено уголовных дел - 2, в суд направлено - 0, в 2014 г. уголовные дела не возбуждались;

- ст. 174 УК РФ «Легализация (отмывание) денежных средств или иного имущества, приобретенных другими лицами преступным путем»: в 2013 г. возбуждено уголовных дел -5 , в суд направлено - 3, в 2014 г. возбуждено уголовных дел - 1 , в суд направлено - 0 .

Не принимались решения о возбуждении уголовных дел по ст. 169 УК РФ «Воспрепятствование законной предпринимательской или иной деятельности», по ст. 170 УК РФ «Регистрация незаконных сделок с землей», ст. 172 УК РФ «Незаконная банковская деятельность» [5] .

Однако, отсутствие возбужденных уголовных дел не означает, что противоправные деяния не совершаются. Зачастую при выявлении преступлений в экономической деятельности наибольшую сложность представляет отграничение уголовно-наказуемого деяния от гражданско-правовых отношений, установление имущественного вреда, размера дохода либо причиненного ущерба, что отличает преступление от административного правонарушения.

Например, для принятия решения о возбуждении уголовного дела по ст. 171 УК РФ необходимо установить крупный размер дохода, для чего потребуется производство бухгалтерской либо экономической судебных экспертиз. Незаконное получение кредита (ст. 176 УК РФ) квалифицируется как уголовно-наказуемое деяние, в случае установления крупного ущерба, что возможно посредством производства финансово-аналитической судебной экспертизы, выводы которой позволят подтвердить наличие либо отсутствие реальной финансовой возможности выполнять обязательства заемщика по кредитному договору, а соответственно - умысел на совершение преступления. Для определения состава преступления, предусмотренного ст. 171.2 УК РФ «Незаконная организация и проведение азартных игр», необходим крупный размер дохода от незаконной деятельности.
В качестве примера следует привести уголовное дело №111367108, возбужденное в августе 2011 г. отделом дознания УМВД России по г. Екатеринбургу по признакам преступления, предусмотренного ч.1 ст. 171 УК РФ[6] . Однако, в ходе проверки сообщения о преступлении не был установлен размер дохода, полученного от незаконной деятельности. В ходе расследования уголовного дела посредством производства экономической судебной экспертизы доход в крупном размере не нашел подтверждения, в связи с чем уголовное дело прекращено по основанию, предусмотренному п. 2 ч. 1 ст. 24 УПК РФ отсутствие в деянии состава преступления[7] . Соответственно, определение размера дохода при проверке сообщения о преступлении позволило бы избежать преждевременного и необоснованного принятия решения о возбуждении уголовного дела, и, как следствие, неоправданных ресурсных затрат (объем уголовного дела составил 47 томов).

Таким образом, производство судебной экспертизы при выявлении экономических преступлений является, прежде всего, обеспечением правильного применения уголовного законодательства, соответственно необходимой предпосылкой для реализации назначения уголовного судопроизводства, предусмотренного ст. 6 УПК РФ.

Однако, анализ уголовно-процессуального законодательства, позволил выявить ряд противоречий, которые на сегодняшний день не допускают возможности производства судебных экспертиз при проверке сообщения о преступлении в экономической деятельности.

Так, заключение эксперта - это представленные в письменном виде содержание исследования и выводы по вопросам, поставленным перед экспертом лицом, ведущим производство по уголовному делу, или сторонами (ч. 1 ст. 80 УПК РФ). Таким образом, назначить судебную экспертизу может лицо, в производстве которого находится уголовное дело, то есть следователь дознаватель. При проверке сообщения о преступлении нет ни уголовного дела, ни производства по нему, ни лица, которое его ведёт.

Далее, из названия и содержания ст. 199 УПК РФ «Порядок направления материалов уголовного дела для производства судебной экспертизы» усматривается отсутствие процессуального механизма назначения и производства судебных экспертиз на основании материалов проверки сообщения о преступлении.

Кроме того, для производства бухгалтерских, экономических, финансово-аналитических судебных экспертиз в распоряжение эксперта необходимо представить определенные материалы 
(первичные бухгалтерские документы, подтверждающие наличие определенной деятельности организации, финансовой и налоговой отчетности и т.д.). Норма ч.1 ст. 144 УПК РФ позволяет в ходе проверки сообщения о преступлении изымать документы и предметы в порядке, установленном уголовно-процессуальным кодексом. Однако, обнаружить и изъять объекты возможно посредством производства следственных действий: осмотр места происшествия, обыск и выемка, последние из которых производятся только в ходе расследования уголовного дела. Процессуальный порядок осмотра места происшествия не позволяет в полном объеме изъять документы, как это было бы возможно при обыске или выемки. Таким образом, вопрос относительно процедуры получения в ходе проверки сообщения о преступлении документов в объеме, достаточном для исследования и формулирования выводов, на сегодняшний день не разрешен. Важным элементом в выявлении экономических преступлений является противодействие со стороны злоумышленников, соответственно добровольное предоставление материалов, интересующих правоохранительные органы, абсолютно исключается.

Отдельное внимание заслуживают вопросы, касающиеся сроков производства бухгалтерских, экономических, финансово-аналитических и др. судебных экспертиз, юридического значения заключения эксперта, процессуального статуса лица, в отношении которого назначается и производится судебная экспертиза.

Таким образом, вопрос о производстве судебной экспертизы по преступлениям в экономической деятельности до возбуждения уголовного дела остается проблемным и требует своего разрешения. Опрос следователей ГСУ ГУ МВД России по Свердловской области, специализирующихся на расследовании экономических преступлений, сотрудников ОЭБ и ПК, экспертов ЭКЦ ГУ МВД по Свердловской области, показал, что при проверке сообщений об экономических преступлениях судебные экспертизы не назначаются и не производятся.

На основании изложенного, представляется возможным сделать следующий вывод:

1. назначение и производство судебных экспертиз при проверке сообщений о преступлениях в экономической деятельности в законодательном порядке не обеспечены.

2. заключения судебных экспертиз, полученные при проверке сообщений о преступлениях, из-за сбоев законодательной техники не могут отвечать требованиям допустимости и признаваться в качестве доказательств.

3. пробелы в законодательном обеспечении возможности назначения и производства судебных экспертиз в стадии возбуждения уголовного дела продолжают оставаться актуальными и требуют теоретического осмысления.

\section{Библиография:}

1. Данные ИЦ ГУ МВД по Свердловской области за 9 месяцев 2013-2014 гг.

2. Трунцевский Ю.В. Экономические и финансовые преступления: учеб. пособие для студентов вузов, обучающихся по специальности 030501 «Юриспруденция» / Ю.В. Трунцевский, О.Ш. Петросян. М.: ЮНИТИ-ДАНА: Закон и право, 2008. - 288 с.

3. Уголовный кодекс Российской Федерации от 13.06.1996 г. № 63-Ф3 (с имз. и доп.) // СПС КонсультантПлюс

4. Уголовно-процессуальный кодекс Российской Федерации от 18.12.2001 г. № 174-Ф3 (с имз. и доп.) // СПС КонсультантПлюс

5. Указ Президента РФ от 12.05.2009 № 537 (в ред. от 01.07.2014 с изменениями, вступившими в силу с 01.07.2014) «О Стратегии национальной безопасности Российской Федерации до 2020 года» // СПС «КонсультантПлюс»

6. Указания Генеральной прокуратуры РФ № 387-11 и МВД РФ № 2 от 11.09.2013 (в ред. от 24.04.2014) «О введении в действие перечней статей Уголовного кодекса Российской Федерации, используемых при формировании статистической отчетности» // СПС КонсультантПлюс

7. Уголовное дело №111367108 // архив СУ УМВД России по г. Екатеринбургу

\section{References (transliterated):}

1. Dannye ITs GU MVD po Sverdlovskoi oblasti za 9 mesyatsev 2013-2014 gg. 
2. Truntsevskii Yu.V. Ekonomicheskie i finansovye prestupleniya: ucheb. posobie dlya studentov vuzov, obuchayushchikhsya po spetsial'nosti 030501 «Yurisprudentsiya» / Yu.V. Truntsevskii, O.Sh. Petrosyan. - M.: YuNITI-DANA: Zakon i pravo, 2008. - 288 s.

3. Ugolovnyi kodeks Rossiiskoi Federatsii ot 13.06 .1996 g. № 63-FZ (s imz. i dop.) // SPS Konsul'tantPlyus

4. Ugolovno-protsessual'nyi kodeks Rossiiskoi Federatsii ot 18.12.2001 g. № 174-FZ (s imz. i dop.) // SPS Konsul'tantPlyus

5. Ukaz Prezidenta RF ot 12.05.2009 № 537 (v red. ot 01.07.2014 s izmeneniyami, vstupivshimi v silu s 01.07.2014) «O Strategii natsional'noi bezopasnosti Rossiiskoi Federatsii do 2020 goda» // SPS «Konsul'tantPlyus»

6. Ukazaniya General'noi prokuratury RF № 387-11 i MVD RF № 2 ot 11.09.2013 (v red. ot 24.04.2014) «O vvedenii v deistvie perechnei statei Ugolovnogo kodeksa Rossiiskoi Federatsii, ispol'zuemykh pri formirovanii statisticheskoi otchetnosti» // SPS Konsul'tantPlyus

7. Ugolovnoe delo №111367108 // arkhiv SU UMVD Rossii po g. Ekaterinburgu 